Contents lists available at ScienceDirect

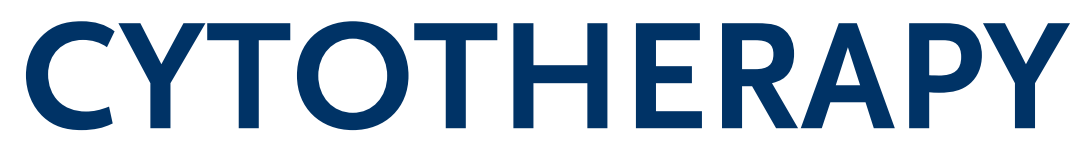

journal homepage: www.isct-cytotherapy.org
International Society

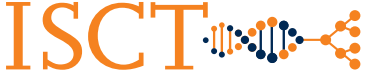

Cell \& Gene Therapy ${ }^{\circledR}$

\title{
A warm welcome to Paris - Virtual!
}

Although the internet has been around for decades, it's only recently that virtual meetings have been at the forefront of everyone's minds - and for good reason. ISCT 2020 Paris Virtual represents an unprecedented opportunity in a time of crisis, as we continue to stand strong in the face of COVID-19. Just as email has mostly replaced snail-mail, ISCT has initiated an accelerated embrace of virtual space to connect members of our truly global society.

From the Organizing Committee's remarkable resilience in turning things around at breakneck speed, to the dedication of our Head Office, to the overwhelming enthusiasm of our membership registering from all around the world, ISCT has done its best to assemble a superb showcase of the best in cell and gene therapy. ISCT 2020 Paris Virtual promises to be a meeting like none before. The eyes of our peers are on us as we have re-imagined a focused program that I'm simply thrilled to introduce here.

We have re-imagined our annual meeting in virtual space! ISCT is taking a leading role in re-designing the program from the ground up. We will provide the same, much-loved sessions that are familiar to regular attendees of every ISCT Annual Meeting. I promise you will enjoy the highest quality education, discussion, and inspiration on the most timely and critical topics in our field today. Our roster of speakers is a handpicked group of key opinion leaders, and our program sessions have undergone peer review, development, and now optimization for the digital sphere.

We are presenting over 30 sessions, with over 50 hours of LIVE and on demand streaming. Live discussion periods are scheduled for many of these. Each of our 6 plenaries concentrates on the latest advances in basic research, pre-clinical studies and clinical trials for therapeutic modalities including MSCs, immune effector cells, exosomes, gene-engineered cells, and iPSCs. Daniel Weiss, our Chief Scientific Officer, has rallied together an exceptional Showcase on COVID-19, featuring reports from the front lines, and a deep dive into how our field is contributing to the fight against the pandemic. Two of our pre-conference tracks have been transformed into Hot Topic sessions, bringing vital and practical information on Strategies for Commercialization, and Quality and Operations.

If you haven't already visited our virtual conference hall, just think of Google Street View for cell and gene therapy sightseers. Wrapped around all this amazing scientific content is a highly interactive and exciting - virtual reality platform. The ISCT 2020 Paris Virtual site houses an interactive exhibition hall, presentation theatres, an abstract e-poster hall with over 500 posters, a partnering forum designed to set up one-on-one and group meetings, and much more. As with every Annual Meeting before, there is a sense of exploration, fun and opportunity for discovery!

On our platform, you will encounter over 1800 fellow attendees navigating throughout the two days of our Meeting. You will see booths and products designed for the web to introduce our sponsors and corporate exhibitors. You will find a virtual environment designed for comfortable, flexible, global access. Never before has it been easier to find what you're looking for at an ISCT Annual Meeting - especially while sitting in your favourite chair.

Our annual meeting this year will also - as you've no doubt seen in our communications so far - endure beyond the live event. For twelve months, until May 2021, our annual meeting will function as a fully accessible and living archive. You can come back to this content, review and replay, comment alongside peers, and follow up with presenters for an unprecedented timeframe.

I am so honoured to be introducing this all to you - and I am deeply grateful for the hard work of our peers and friends that has driven this meeting to fruition.

Our ISCT 2020 Paris Virtual sponsors are diverse and numerous. I thank each of our Sponsors for supporting our vision of a virtual meeting with unusually short notice. To our friends at Maxcyte, Cytiva, and Penn Medicine - our diamond sponsors - I am humbled by your belief in what ISCT has to offer even in unprecedented terrain. I offer a heartfelt thank you. This year has been something of a roller coaster for everyone, but now we plan to enter calmer waters as we together sing "it's a small world after all".

Our ISCT 2020 Paris Virtual Organizing Committee has been tireless in reworking and adapting our Paris program into the inspiring suite it is now. I want to offer profound thanks on behalf of ISCT to the whole committee - and special thanks on top of this to Christian Chabannon, Rachele Ciccocioppo, and Ivan Martin. In just weeks they have spearheaded a resilient and flexible approach to adapting our Annual Meeting plans that typically take more than two years to refine. The success of ISCT 2020 Paris Virtual will be a testament to their strong commitment under challenging circumstances - no one originally signed up to organise an international meeting during a pandemic.

I've always seen ISCT as a beacon to everyone involved in cell and gene therapy. At this moment, as I approach the end of my Presidential term, I have no doubt that our Society will continue to attract and showcase the best of the best. 
I know this is a meeting that will inspire, inform, and connect us as a Society. I hope that all of you find that this offers a beautiful moment to enjoy in the troubling times that we have been withstanding every day. So please get your avatars activated - because soon we will be virtually standing face-to-face!
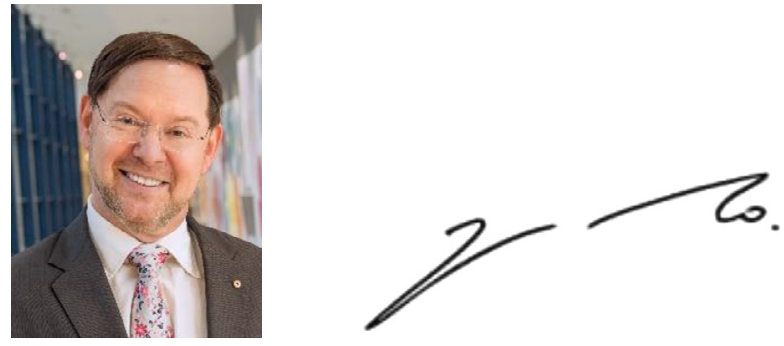

John Rasko, AO, BSc(Med), MBBS(Hons), PhD, MAICD, FFSc(RCPA), FRCPA, FRACP, FAHMS

ISCT President, 2018-2020 